\title{
TEKTONICKÉ PORUŠENÍ NEOGÉNU JIŽNÍ ČÁSTI KARPATSKÉ PŘEDHLUBNĚ V OKOLÍ HEVLÍNA
}

\author{
Tectonics of Neogenous rocks from the Southern part of Carpathian Foredeep in the Hevlín \\ surroundings
}

Otáhalová Marie, Rostislav Melichar

Ústav geologických věd, Prírodovědecká fakulta, Masarykova univerzita, Kotlářská 267/2, 61137 Brno;

e-mail:423689@mail.muni.cz; melda@sci.muni.cz

(34-14 Mikulov)

Key words: tectonics, Neogene, Carpathian Foredeep, normal faults, paleostress analysis

\begin{abstract}
In the locality Hevlin, deformation zone with a dense network of small faults was recognized in Neogene clay of the Carpathian Foredeep. Faults are striking in N-S to NW-SE direction and dipping from E to NE. Two systems of striae were found on fault surfaces. The older one is plunging under medium-sized angles, while the younger is almost sub-horizontal. Corresponding older stress phase has orientation $\sigma_{1} 273^{\circ} / 69^{\circ}, \sigma_{2} 98^{\circ} / 21^{\circ}$ and $\sigma_{3} 7^{\circ} / 2^{\circ}(\mu=-0.61)$, and younger $\sigma_{1} 333^{\circ} / 43^{\circ}, \sigma_{2} 70^{\circ} / 7^{\circ}$ and $\sigma_{3} 167^{\circ} / 46^{\circ}(\mu=-0.31)$. These orientations do not match Anderson's theory of fracturing and could be perhaps explained by permeating of movements on some fault in the bedrock.
\end{abstract}

Úvod

V cihelně u Hevlína byly studovány neogenní vrstvy porušené poněkud nezvyklým způsobem. Rekognoskací zde byla zjištěna deformační zóna s hustým výskytem drobných zlomů, které prokazovaly opakovanou aktivaci. Lokalita se ukázala natolik zajímavou, že bylo vhodné provést zde podrobnou paleonapjatostní analýzu.

Zájmová oblast Hevlína leží v jižní části karpatské předhlubně vyplněné neogenními sedimenty (Brzobohatý 2002). V roce 1967 byla lokalita označena jako hypostratotyp stupně karpat (Cicha et al. 1967). Revize této lokality byla provedena $\mathrm{v}$ roce 2003 (Doláková et al. 2003). Lokalita byla podrobně studována zejména z paleontologického, př́íp. ze sedimentologického hlediska (Doláková et al. 2016). Vlastní lokalita slouží jako jíloviště pro místní cihelnu, $\mathrm{z}$ hornin zde převažují vrstevnaté jíly karpatu zbarvené do šedé až modrošedé barvy, které jsou spíše hlinité, př́íp. slabě písčité, stř́ípkovitě rozpadavé. Vrstvy jílů jsou horizontálně uložené a tektonicky obecně málo porušené.

\section{Metodika a původ dat}

Terénní práce byly provedeny na jaře roku 2016.
Místo s hustým drobně zlomovým porušením bylo na základě upozornění dr. Dolákové nalezeno v rohové části jezírka zatápějícího nejnižší část jíloviště (obr. 1). V severovýchodním rohu jezírka byly odkopány zlomové plochy, na nichž byly sledovány stopy pohybu v podobě tektonického rýhování. Orientace zlomových ploch byla měřena spádnicovým způsobem geologickým kompasem typu Freiberg ve stupních. Celkem byla změřena orientace 12 zlomových poruch s rýhováním. Vždy byla změřena plocha i rýhovaní na stejném místě. Poměrně nerovinné zlomové plochy způsobily vyšší chybu měření a odchylky linií rýhování od ploch. Protože rýhování byla po odkopá-

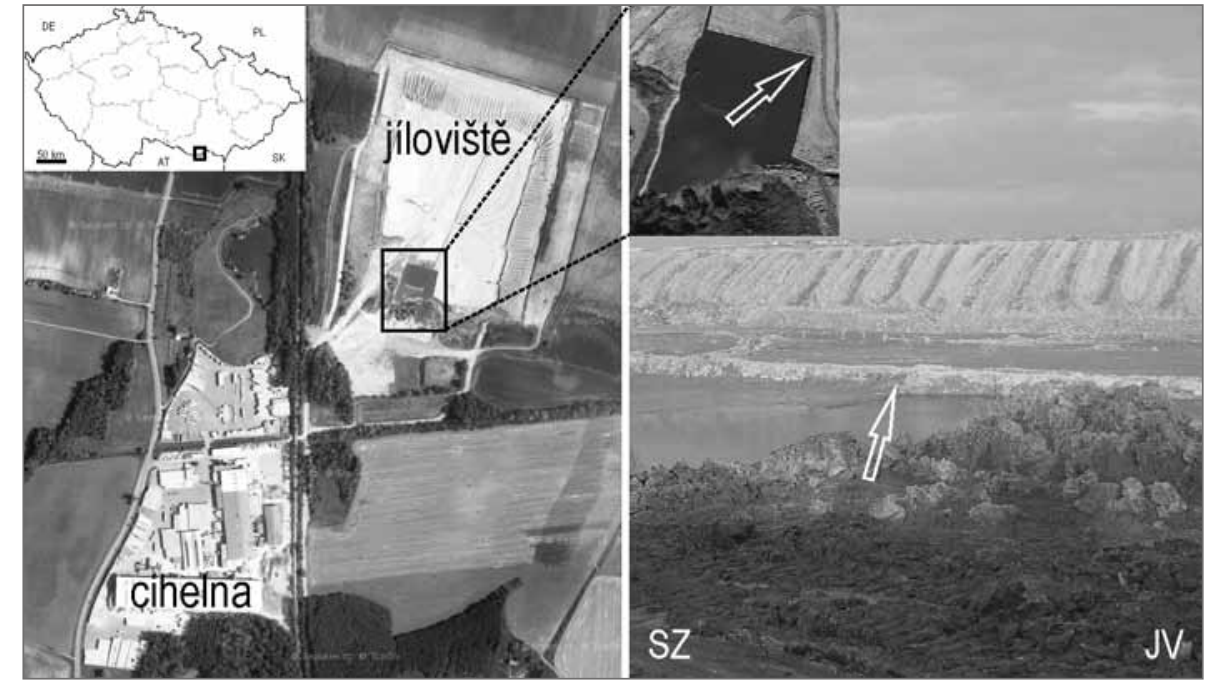

Obr. 1: Poloha studované lokality Hevlín a místo výskytu zlomů (podklad www.mapy.cz). Fig. 1: Settings of the locality Hevlín and localization of fault occurrence (background www.mapy.cz). 


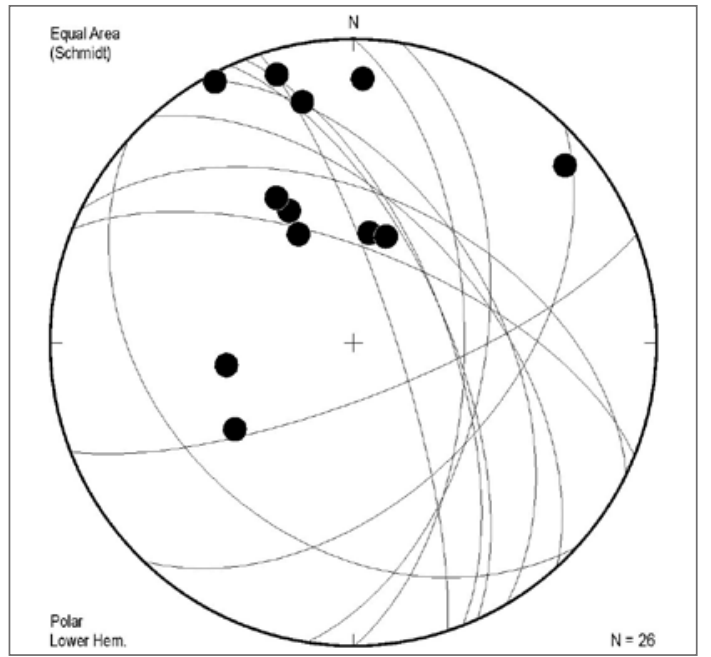

Obr. 2: Orientace zlomových ploch (oblouky) a rýhování (body) na lokalitě Hevlín, neogenní jíly karpatské předhlubně.

Fig. 2: Orientation of fault surfaces (great circles) and striae (points) at Hevlín quarry, Neogenous clay, the Carpathian Foredeep.

ní zřetelná jen na některých částech ploch zlomů, je počet zlomů dán počtem měřitelných rýhování. Na rýhování byly sledovány asymetrické struktury k určení smyslu pohybu na zlomech. Velká část zlomů vykazovala rýhování dvou různých směrů. Ojediněle se podařilo rozpoznat vzájemné stáří tektonických pohybů.

Naměřená data byla zpracována metodami orientační analýzy v programu Spheristat 3.1. Byla užita azimutální rovnoplochá Lambertova projekce na spodní polokouli. Paleonapjatostní analýza byla zpracována v programu MARK2010 (Melichar - Kernstocková 2010; Kernstocková 2011). Při tom byly určeny směry hlavních normálových napětí $\sigma_{1} \geq$ $\sigma_{2} \geq \sigma_{3}$, kde $\sigma_{1}$ je komprese a $\sigma_{3}$ je relativní extenze. Vedle směrů byl stanoven i tvarový parametr elipsoidu napjatosti - tzv. Lodeho parametr (Lode 1926).

\section{Výsledky}

Zjištěné zlomové plochy mají převážně směr S-J až SZ-JV se strmým až středním úklonem $\mathrm{k} \mathrm{V}$ až SV. Jen ojediněle byly dokumentovány i zlomy jiného směru (obr. 2). Rýhování na zlomových plochách se sklání dominantně k SSZ pod velmi mírným nebo středním úklonem, přičemž obě skupiny rýhování jsou zřetelně sklonově odděleny. Ojediněle byly zjištěny i jiné směry rýhování (SV-JZ). Smysly pohybu podél rýhování ukloněných k SSZ měly poklesovou kinematiku, resp. šikmou poklesovou kinematiku s podstatnou levostrannou složkou pohybu. Podle vztahů obou typů

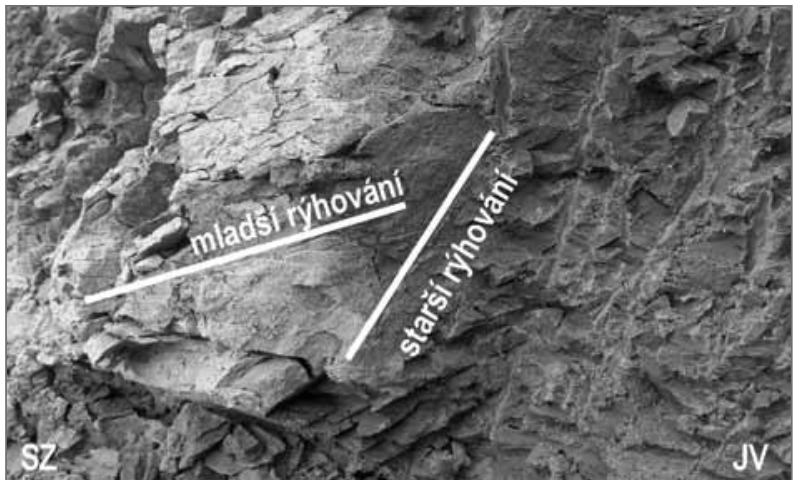

Obr. 3: Vztah dvou generací rýhování na ploše zlomu.

Fig. 3: Relationship of two striation systems on one fault surface.

rýhování (obr. 3) bylo možno konstatovat, že strmější rýhování $\left(\mathrm{L}_{1}\right.$ 17/60) je hrubší a starší než jemnější subhorizontální rýhování $\left(\mathrm{L}_{2} 344 / 9\right)$. Zajímavá je vysoká hustota zlomů, která extrémně dosahovala takové míry, že zlomy téže orientace byly vzájemně vzdáleny pouze 2 až $3 \mathrm{~cm}$ při velikosti pohybu několika milimetrů až prvních centimetrů. Vzájemný vztah těchto paralelních zlomů nebylo možné pozorovat.

Při napjatostní analýze byly vymezeny dva napjatostní stavy - dvě deformační fáze. Napjatostní stav starší deformační fáze (obr. 4) měl kompresní hlavní normálové napětí $\sigma_{1}$ subvertikální v orientaci 273/69, střední hlavní normálové napětí $\sigma_{2}$ bylo mírně ukloněné v. až jv. směrem s orientací $98 / 21$ a extenzní hlavní normálové napětí $\sigma_{3}$ vyšlo subhorizontální směru SSV-JJZ (orientace 7/2). Zjištěný Lodeho parametr má hodnotu $\mu=-0,61, \mathrm{tj} . \sigma_{2}$ se
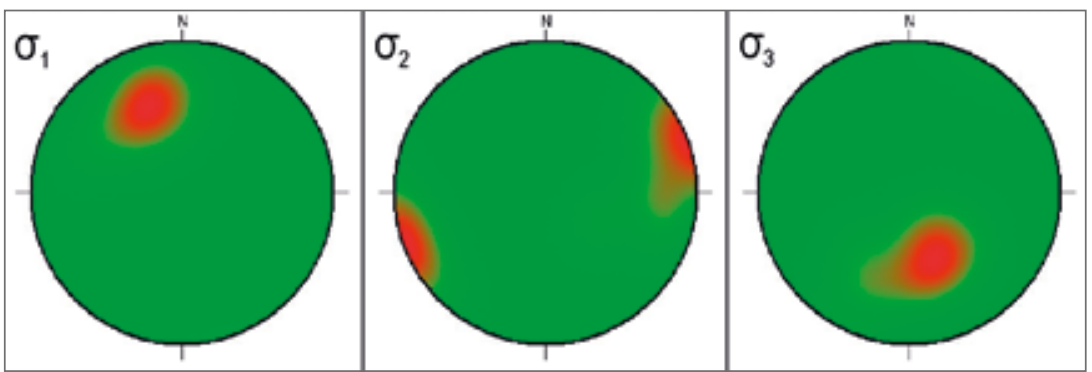

Obr. 4: Konturové diagramy ukazující směry hlavních normálových napětí starší fáze $\sigma_{1}=273 / 69, \sigma_{2}=98 / 21, \sigma_{3}=7 / 2$ z lokality Hevlín, výstup z programu MARK2010.

Fig. 4: Contour plots showing directions of principal stresses of older phase: $\sigma_{1}=273^{\circ} / 69^{\circ}$, $\sigma_{2}=98^{\circ} / 21^{\circ}, \sigma_{3}=7^{\circ} / 2^{\circ}$ from the site Hevlín, output from MARK2010 software.
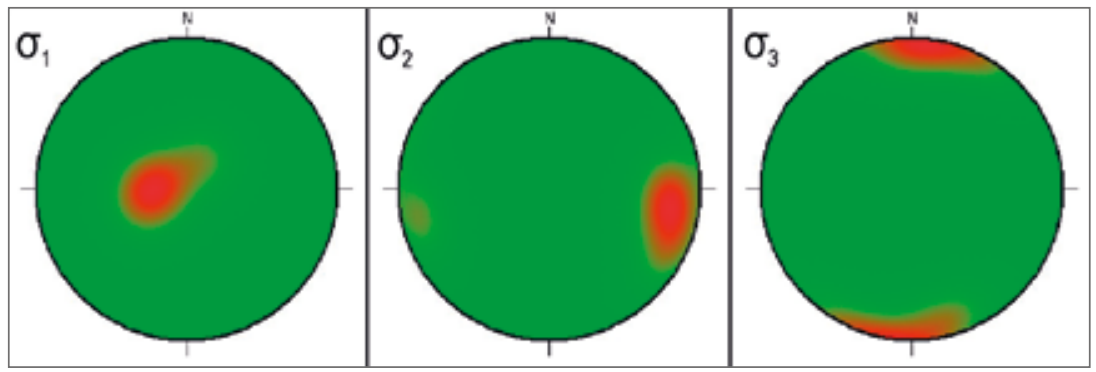

Obr. 5: Konturové diagramy ukazující směry hlavních normálových napětí mladší fáze $\sigma_{1}=333 / 43, \sigma_{2}=70 / 7, \sigma_{3}=167 / 46$ z lokality Hevlín, výstup z programu MARK2010. Fig. 5: Contour plots showing directions of principal stresses of younger phase: $\sigma_{1}=$ $333^{\circ} / 43^{\circ}, \sigma_{2}=70^{\circ} / 7^{\circ}, \sigma_{3}=167^{\circ} / 46^{\circ}$ from the site Hevlín, output from MARK2010 software. 
svou hodnotou výrazně blíží velikosti $\sigma_{3}$. Do starší fáze byly přiřazeny zlomy s rýhováním středně strmým $\left(\mathrm{L}_{1}\right)$.

Pro mladší tektonickou fázi (obr. 5) bylo zjištěno kompresní napětí $\sigma_{1}$ středně ukloněné k SSZ (333/43), střední napětí $\sigma_{2}$ subhorizontálního směru VSV-ZJZ (70/7) a extenzní napětí $\sigma_{3}$ středně ukloněné k JJV (167/46). Pro tuto fázi měl Lodeho parametr hodnotu $\mu=-0,31$. Během mladší fáze byly reaktivovány dříve vytvořené zlomy za vzniku subhorizontálního rýhování.

\section{Diskuze a závěr}

Orientace hlavních normálových napětí získané paleonapjatostní analýzou jsou poměrně neočekávané. Standardní orientace napjatostí mladých zlomů obvykle respektují Andersonovu teorii vzniku zlomů (Anderson 1942), kdy jedno $\mathrm{z}$ hlavních normálových napětí $\left(\sigma_{1}, \sigma_{2}\right.$, $\left.\sigma_{3}\right)$ má subvertikální orientaci. Takovou orientaci lze př̀i určité toleranci vidět pouze u starší fáze, zatímco fáze mladší takové představě odporuje. Hypoteticky by to mohlo být způsobeno různými faktory, jako např. rotací bloků, deformačními nehomogenitami apod.

Podezření, že by se jednalo o druhotné deformace spojené s těžbou nebo gravitačními pohyby vyvolanými vznikem deprese jíloviště lze s poměrně vysokou jistotou vyloučit. Jednak je soubor rýhování směrově poměrně homogenní i na vzdálenost několika jednotek až prvních desítek metrů, jednak paleonapjatostní analýza ukázala existenci dvou homogenních tektonických fází. Navíc orientace zlomů na odkryvu byla spíše protiklonná (převislá). Rovněž prítomnost subhorizontálního rýhování mluví proti druhotnému vzniku. Lze tedy oprávněně předpokládat, že se jedná o projevy tektonické. Rovněž rotaci bloků lze poměrně jasně vyloučit vzhledem $\mathrm{k}$ zachovalé horizontální pozici vrstev studovaných sedimentů. Jednou z mála reálných možností tektonické interpretace nalezených struktur, které prokazatelně vznikaly v těsné blízkosti povrchu a nesouhlasí s Andersonovou teorií vzniku zlomů, je reakce na pohyby na zlomech v krystalinickém podloží. Ty se mohou složitě prokopírovávat do pokryvu, ve kterém pak mohou vytvářet druhotné deformační zóny. Ani tento mechanismus však zjištěnou disproporci nevysvětluje zcela bezroblémově. Přesnou interpretaci je tak za stávajícího stavu znalostí nutno nechat otevřenou.

\section{Poděkování}

Autoři děkují zejména paní RNDr. Nele Dolákové, CSc., za upozornění na toto zajímavé místo. Dále patří dík editorce Mgr. Pavle Tomanové Petrové, Ph.D., a recenzentưm za cenné rady a připomínky ke článku, které přispěly k jeho zkvalitnění.

\section{Literatura}

Anderson, E. M. (1942): The Dynamics of faulting. - Oliver and Boyd. Edinburgh.

Brzobohatý, R. (2002): Neogenní pánve na Moravě. - In: Chlupáč, I. - Brzobohatý, R. - Kovanda, J. - Stráník, Z. (eds): Geologická minulost České republiky, 344-353. Academia. Praha.

Brzobohatý, R. - Cicha, I. (1993): Karpatská předhlubeň. - In: Přichystal, A. - Obstová, V. - Suk, M. (eds): Geologie Moravy a Slezska, 123-128. MZM a Sekce geol. věd PřF MU. Brno.

Cicha, I. - Ondrejíčková, A. - Seneš, J. - Špička, V. - Tejkal, J. - Zapletalová, I. (1967): Holostratotypus und Faziostratotypen des M3 (Karpatien). - In: Cicha, I. - Seneš, J. - Tejkal, J. (eds): Chronostratigraphie und Neostratotypen, Miocän M3 (Karpatien) , 50-102. SAV. Bratislava.

Doláková, N. - Hladilová, Š. - Petrová, P. - Švábenická, L. - Zlinská, A. - Halásová, E. - Andreyeva-Grigorovich, A. S. - Kvaček, Z. (2003): Hypostratotypes of the Karpatian Stage. - In: Brzobohatý, R. - Cicha, I. - Kováč, M. - Rögl, F. (eds): The Karpatian - A Lower Miocene Stage of the Central Parathethys, 21-26. Masaryk University. Brno.

Doláková, N. - Holcová, K. - Pouzot, Ch. (2016): Hevlín. - In: Tomanová Petrová, P. (ed.): Molasse Meeting 2016 \& 18th Conference on Upper Tertiary: excursion guide: Brno, 26-27 May 2016, 28-33. Masaryk University. Brno.

Kernstocková, M. (2011): Paleonapjatostní analýza polyfázově reaktivovaných zlomů na př́kladu barrandienu. - MS, disertační práce. Př́rodovědecká fakulta Masarykovy univerzity. Brno.

Lode, W. (1926): Versuche fiber den Einfluß der mittleren Hauptspannung auf das Fließen der Metalle Eisen, Kupfer und Nickel. - Zeitschrift für Physik, 36, 11-12, 913-939. DOI: 10.1007/BF01400222.

Melichar, R. - Kernstocková, M. (2010): 9D space - the best way to understand paleostress analysis. - Trabajos de Geología, 30, 69-74. Universidad de Oviedo. Ovideo. 